\title{
The Reality of Online Education by the Busiest Japanese Teachers in Public Primary and Junior High Schools under COVID19 in Japan
}

\author{
Osamu IKEDA
}

\author{
Department of English Language and Literature, Faculty of Language and Literature, Bunkyo University, Japan \\ Email: z500974@bunkyo.ac.jp
}

\begin{abstract}
The COVID19 pandemic began to assault the Japanese archipelago in January 2020. In educational fields, school lessons were suspended to prevent the spread of the Corona virus infection under a state of emergency, declared by the Japanese Prime Minister, Shinzo Abe, in the Spring of 2020. Initially, schools had to change face to face lessons to assignments, or self-study by the students. Teachers gave lesson handouts for the students from February to March, in 2020. The Japanese government hoped public schools would make good use of computers to support good educational outcomes. This paper aims at reporting on the current educational situation for Information Communication Technology (ICT) under the Corona virus pandemic, for metropolitan Tokyo in Japan, from the January of 2020 to August 2021. This paper discusses how much the busiest teachers in the world utilize ICT for lessons in one of the world's most developed countries, Japan, despite Japanese teachers already working the longest hours per week of any country.
\end{abstract}

Keywords: Online education, teacher, remote, ICT, COVID 19, corona, Japan

\section{INTRODUCTION}

\subsection{The COVID19 situation in education in Japan.}

The Director-General of the World Health Organization (WHO), declared the COVID 19 Corona virus outbreak a pandemic on 30 January 2020. In Japan, the first Corona virus carrier was found on 15th January 2020[1]. Between January 2020 and 17 August 2021, the number of Corona virus infections has totalled approximately 120000 people and 15000 people have died. From January 2020 to September 2021, a state of emergency has been declared five times by the Japanese government in Tokyo, along with three of the surrounding prefectures. However, unlike European countries, the government could not lock down every city. The current Japanese constitution does not allow the government to restrict the freedom of people to go out. The government just requested that the people stay home and avoid gathering in crowded areas and commuting on crowded public transportation. Bars and restaurants were obliged to close before $8.00 \mathrm{pm}$ and were requested by the government not to provide alcohol. Also, all schools; primary, junior high, and high school, except nursery and kindergarten schools, were requested by Prime Minister Shinzo Abe, to close temporarily from 28 February up to the Spring holiday, which is normally 14 March 2020.[3] However, this government request for schools to close was not formally compulsory, although the impact of the request by the prime minister did largely influence the schools' response.

Suddenly, teachers and schools had to halt the rest of the curriculum and school activities, and the usual seasonal events. When the new semester commenced from 7 April, after the Spring holiday, public schools and teachers were not able to rely on computers for remote teaching immediately, for their students. This situation arose because the ratio of students using Information Communication Technology (ICT) at that time, was too low to completely adapt to digitally driven education, by public schools. Furthermore, not enough teachers were familiar with teaching via an online environment. Therefore, most teachers were obliged to provide lesson handouts or simply give instructions for students to study by themselves, instead of teaching via online methods. 


\subsection{Why did this research decide to focus on the reality of online education by the world's busiest Japanese teachers under COVID 19?}

Three difficulties exist for teachers in Japan. Firstly, the working hours for teachers are the highest in the world. Secondly, the requirement for teachers to perform clerical work already contributes to a heavy workload. Thirdly, access to ICT capability has huge discrepancies between households, in Japan. These three factors obstructed the uniform adoption of online education in public schools, during the pandemic.

In addition to these difficulties, the Corona virus pandemic itself impacted the schools. Teachers were required to become familiar with computer and online software, such as Zoom and Google classroom, during the short term after the Spring holiday. It is probable that some teachers who were not familiar with computer learning technology struggled to become accustomed to using online lessons. Many pupils, students and their parents also struggled to prepare for online educational scenarios. In these difficult situations, this paper researches whether or not the busiest teachers in the world can handle teaching through online education portals. The online education reality in Japanese public primary and junior high schools is analysed in this paper.

\section{LITERATURE REVIEW}

Firstly, this chapter considers the impact of long working hours for Japanese teachers, the stress levels of Japanese teachers in comparison to the rest of the world, and the low ratio of implementing ICT for education in Japan. These three circumstances strongly influence current online education.

In the first topic, "The longest Japanese teachers' working hours in the world, experienced by Japanese teachers" is a result of Japan's own educational system. The Japanese teachers' long working hours must be addressed in detail in this paper. It is possible that the demands of the long working time are creating a barrier to the mastering of new skillsets.

In the second topic, "Japanese teachers' stress levels in comparison to the rest of the world" analyses what tasks limit and impact on a teacher's available time to learn new skills.

The third topic is, "The low ratio of accessing ICT for education in Japan". Although Japan is a developed country, actually ICT for education purposes in Japan falls behind the rest of the world.

\subsection{The longest Japanese teachers' working hours in the world.}

This paper needs to address Japanese teachers' working hours per week. Their working hours were found to be the longest in the world, in 2013 and 2018 [4]. According to the OECD, The Teaching and Learning International Survey (TALIS), in 2018, reported that working time for Japanese teachers in a week was 53.9 hours, on average. Primary school teachers' working time per week was an average of 54.4 hours. For Junior high school teachers, the average is 56.0 hours per week. The world average for teachers' working hours is $\mathbf{3 8 . 3}$ hours. Comparing working hours in Japan to the rest of the world, Japanese teachers exceed the international average by $\mathbf{1 5 . 8}$ hours per week, which is approximately $\mathbf{3 . 1}$ hours per day. The average of Japanese teachers' working hours per day is approximately 11 hours. This situation causes a negative impact on a teacher's ability to acquire new skills.

\section{In the case of primary schools}

In the case of teachers in primary schools in Japan, primary school teachers basically have to teach all subjects alone, namely, the management system is engaged in primary schools. The subjects taught include the Japanese national language, mathematics, society, science, music, sports, craftwork, household, and morality. Additionally, English language, computer programming, and dancing were added as new subjects, in 2020. Primary school teachers are burdened with teaching a wide variety of subjects alone.

\section{In the case of public Junior high schools}

In the background of the longest teachers' working hours in junior high schools, is the requirement for unique Japanese own school activities. All teachers in junior high school have to teach sports and liberal arts activities such as English, music, art, and craft on a daily basis and club activities after the teaching subjects. Then, teachers in junior high schools have to allow time for club activities daily, on weekdays and at the weekend as well. These Japanese own activities cause stress for teachers, who are also required to take extra time to learn new teaching skills.

The National Institute for Educational Policy Research in Japan recognized that there is a big problem for junior high school teachers having to be involved in club activities such as sports and liberal arts, which are activities that are not related to classroom teaching subjects. This is a long-term problem. Furthermore, the institute pointed out that there was a lack of human resources in schools to provide assistance and support to the teachers for these additional activities, and not enough support to assist handicapped pupils who deal with mental and physical problems [5]. 
Japanese teachers work the longest hours, compared with any other teachers around the world. On the other hand, they have the shortest length of time in the world, for their required professional development. Japanese teachers find it considerably difficult to secure enough time to acquire new pedagogical and technological skills, and expertise during their working hours.

\subsection{Japanese teachers' stress levels in comparison to the rest of the world.}

Statistics measuring stress levels in Japanese teachers was the subject of new research in TALIS, measured by the OECD since 2018. The National Institute for Educational Policy Research in Japan focused on what tasks are most stressful, according to the TALIS statistics. The most stressful aspect of a primary or junior high school teacher's work was found to be the additional clerical tasks, such as filling out documents. $61.9 \%$ of primary school teachers and $52.5 \%$ of junior high school teachers felt that the clerical tasks were the most stressful aspect of their job. The world average was $46.1 \%$. The second most stressful aspect of their work was dealing with parents. $47.6 \%$ of primary school teachers and $43.5 \%$ of junior high school teachers felt stressed dealing with parents, compared to a world average of $32.0 \%$ [5].

\subsection{Low ratio of accessing ICT for education in Japan.}

Research by SATO (2021) revealed that only 5\% of primary and junior high school students utilized ICT for online lessons. This is despite the Japanese Ministry of Education, Culture, Science and Technology requesting all schools to use ICT to assist students to learn subjects when school was closed in the Spring of 2020, for three months from the end of February to April 2020. Some households didn't own a computer and did not have broadband internet access. Because there were huge gaps in access to a computer and WIFI technology in so many homes, it was impossible for most schools to conduct remote lessons for all students during the initial term of the COVID 19 pandemic [6].

The National Institute for Educational Policy Research in Japan published their statistics, which were based on TALIS in 2018, by the OECD. It summarized the Japanese teachers' difficult circumstances for trying to provide ICT education [4][5]. Even though ICT education was used in schools, the ratio of teachers with students using ICT for assignments and lessons in class was only $24.4 \%$ in primary schools and $17.9 \%$ in junior high school, compared to the world average which was $51.3 \%$. The ratio of teachers assisting with ICT technology for students to study was $38.5 \%$ in primary schools and $35.5 \%$ in junior high schools, compared to the world average which was $66.7 \%$. These figures clearly reveal that the use of ICT for education was very limited.

\section{METHODS}

\subsection{Research question}

First question

To what extent do Japanese public schools utilize ICT for education during the Corona virus pandemic?

Second question

Do the busy Japanese teachers have enough time to master ICT, on top of such a heavy existing workload, during the Corona virus pandemic?

\subsection{Research Design}

Qualitative research is adopted in this paper. The details that quantitative research cannot evaluate will be determined through interviews with teachers. Only a limited number of teachers can be interviewed during the short term. The researcher will conduct the interviews face to face with the interviewee. If the interviewees do not wish to give their name for this paper, they will remain anonymous.

\subsection{Data Collection}

Data collection was conducted from August to September, in 2021, in metropolitan Tokyo, Japan. Ten teachers in primary schools and junior high schools were interviewed. All of them were engaged in teaching online in schools. Additionally, an ICT supporter who teaches the teachers how to use the computer and software was interviewed. ICT supporters, who are employed by a private computer company, were dispatched to several public schools by the Japanese government.

The primary data from the qualitative research is in the form of words and statements. The researcher used recording devices and took memos for their statements. The researcher obtained permission to record the interviewee's statements and take memos. There were five public primary school teachers and five public Junior high school teachers interviewed. The ten teachers interviewed were all located solely in metropolitan Tokyo.

\section{FINDINGS AND DISCUSSION}

This chapter shows that some factors and backgrounds obstruct online education by teachers' statements.

Mr. Kihata, who is an English subject teacher in a public integrated primary and junior high school in Tokyo, stated that parents hoped children would study face to face with their teachers in their school classrooms. They felt that children trying to study at home disturbed the household and interrupted the remote work being 
performed by parents in the home. Meanwhile, pupils and students missed the security and familiarity of their classrooms and missed playing and socializing with their friends. These two reasons convinced principals to open their schools for students to attend, instead of conducting remote lessons. Additionally, after the Tokyo Olympics were held from 7 July to 8 August under COVID 19, parents requested schools to give students lessons face to face in their classrooms and provide club activities in school. Since the global Olympic games were held under COVID 19, parents reasoned that school sports club activities and competitions should also be conducted as normal, the same as the Olympic games were. Many parents criticised the Japanese government and the Tokyo metropolitan government's attitude toward limiting school activities. Therefore, schools shifted sports activities with students gathering up from online selftraining for students.

Furthermore, an anonymous teacher disclosed that Japanese teachers did not secure extra time and energy to master online educational systems, even though the ICT supporters, tasked with helping teachers to learn and operate computers, did teach them how to use the technology. A teacher's working day is more than 11 hours or more. Most teachers cannot find the time to use computers for online education because they already had to manage too many tasks. The number of online lessons being conducted is decreasing in public primary and junior high schools, in Japan. This is despite the number of Corona virus cases increasing since the beginning of the pandemic, up to the end of August 2021.

Another anonymous teacher mentioned that the Olympics, which were held on 8 August 2021, during the pandemic had an indirect influence on education. Due to the Olympics games being held even during a state of emergency, parents reasoned that schools could also give face to face lessons and provide school sports activities.

Mr. Yoshioka, who is a teacher in a public primary school in Tokyo, explained the online education situation during the COVID 19 pandemic. He stated that public primary schools and teachers have used ICT, but with limited cases.

In the case of events where all students would be gathered close together, online systems are used to avoid spreading the virus. For morning assembly, all the students keep to their classroom and participate by watching the principal talking on their tablet, using WIFI. On sports days, only the competition participants are permitted out on the school grounds to join the competition. Other students watched the sporting events and supported them via an internet connection to their tablet, in their classroom. When practising music, the music teacher played music through an online connection, and all the students would just hum the songs, instead of uttering the words in the classroom, to ensure everybody's safety and reduce the risk of spreading the Corona virus infection.

The schools plan to organize the usual school arts festival this fall. They will utilize online connections for the school arts festival, in the same way they have done for the school sports days. Only one class at a time will perform drama in the assembly hall. Their performance will be viewed through the online connection, for each classroom.

In the case of ordinal subjects, normally teachers taught the subject face to face with students in the classroom up until July 2020. Now, all teachers and students are obliged to wear masks, with a protective transparent partition on each student's desk. When a student tests positive for Corona virus, only the students in their class are shifted from learning in the classroom to self-studying in their home, for two weeks. Within two weeks, using online education was conducted only in a day. Students have to study by themselves, with handouts which the teachers provide to their parents. This is even though the Japanese government have already provided tablets for each student and mobile WIFI devices for each household that does not already access a WIFI service.

Yoshioka's school is considering what method of teaching will be best for the second semester, while the Corona virus Delta strain is spreading into the younger generation. Mr. Yoshioka has already taught students to practice studying with their tablets via online access in the classroom every day, in order to be able to provide online lessons for students for the second semester.

However, the teachers' ICT abilities are different in his school, although the ICT situation of remote teaching has already commenced for students and teachers. Only $30 \%$ of the teachers are familiar with computer technology and the associated software, for remote teaching in his school. This group of teachers can operate computers and solve computer problems by themselves. In the middle group, $50 \%$ of teachers can teach remotely through computers only if teaching how to use computers for the middle level of teachers. In the lower group, $30 \%$ of teachers do not have the abilities or motivation to use computers and teach online. They do not want to teach using these methods. In particular, public school teachers will not be fired by the government, even though they cannot use computers, because government workers are in the guarantee of status by the government. Fortunately, they can teach subjects face to face in classrooms, even under the Corona virus pandemic, at the present time.

An anonymous teacher from a public primary school said that there were some parents who were also not good at using computers. Teachers were obliged to instruct parents on how to set up and operate computers. Considering the teachers' additional workload, they hope to avoid using online lessons. 
An anonymous ICT supporter for teachers mentioned that some teachers in public schools apparently lack the expertise to use computers.

\section{CONCLUSION}

Online lessons were expected to accelerate in schools in Japan, under the Corona virus pandemic. However, most public primary and junior high schools have utilized online lessons in the classroom to ensure that students did not gather in large numbers for assemblies or other events. Most schools basically conduct face to face lessons for each subject in the classroom. Online lessons are considerably limited. Being limited to ICT for lessons in schools is the main reason why infection levels of the Alpha and Beta Corona virus strains were not as strong as for the Delta strain, for teenagers and children. There were not a large number of Corona virus carriers in the younger generation until August 2021.

Secondly, some teachers were not familiar with utilizing computers and teaching online. Most teachers were accustomed to teaching lessons face-to-face with their students. In fact, public schools provided the opportunity to train teachers to use ICT methods. However, some teachers do not have enough time to become accustomed to practising ICT teaching methods due to the demands of many other regular tasks. Teachers' workloads are already too demanding to enable them to also master teaching remote lessons, become familiar with computer software, and learn the methods of teaching remotely.

Thirdly, parents requested that their children be allowed to attend school. During the initial term of the Corona outbreak, most workers did not need to commute by crowded public transport such as bus and train, since many companies permitted their employees to work from home, remotely. But they had to share the house with their children every day, who were supposed to be learning remotely. However, the children interrupted the parents working from home. Also, the parents wanted their children to study at school in the classroom and be able to play with their friends. Consequently, parents wanted their children to attend school. Furthermore, some parents do not accept the costs of having an internet connection for their children to take online lessons.

This paper concludes that the above three reasons were why schools did not pursue online education in public schools. However, since the beginning of September 2021, the Corona virus Delta strain is spreading to the younger generation, including primary and junior high school students, teenagers, and people in their twenties, in Japan. In the second term, following Summer vacation, it is highly possible that online teaching will take a leading role in providing lessons, for public schools.

ICT educational devices such as tablets, and WIFI for each household, and digital textbooks, have been prepared for teachers and students. Theoretically, ICT education is possible in Japan. But some teachers avoid conducting ICT education, because of insufficient ICT abilities and training. ICT training for all teachers will become essential. The Ministry of Education's, educational committee in local government should set some time aside for the busiest teachers to learn ICT, by conducting a policy to reduce other tasks for teachers. In the near future, it is desirable that ICT education will be conducted and accelerated in all public schools.

ICT is such a useful tool for the educational field but people still prefer for students to learn from teachers face to face, in the classroom. People want to see and communicate with, teachers directly face to face, in person. Communication via face to face contact must be an inherent part of human instincts. This will be necessary to examine in the next research.

\section{REFERENCES}

[1] The Asahi Shimbun Company, COVID19 Japanyearly,2021,

DOI:https://www.asahi.com/special/corona/japanyearly/, [Accessed 17 ${ }^{\text {th }}$ Aug 2021]

[2] Japanese Ministry of Health, Labour and Welfare, 2021, COVID 19 infectious situation

DOI:https://www.mhlw.go.jp/stf/covid19/kokunainohasseijoukyou.html, [Accessed 17th Aug 2021]

[3] Japanese Ministry of Education, Culture, Science and Technology, Closed all schools of relations, 2021, DOI:https://www.mext.go.jp/a menu/coronavirus/ mext_00006.html, [Accessed 17th Aug 2021]

[4] OECD, The Teaching and Learning International Survey, 2018, DOI:https://www.oecd.org/education/talis/TALIS 2018_Technical_Report.pdf, [Accessed 17th Aug 2021]

[5] National Institute for Educational Policy Research in Japanese Ministry of Health, Labor and Welfare, Point of Report of OECD TALIS, 2018 vol2, DOI:https://www.nier.go.jp/kokusai/talis/pdf/tails2 018-vol2.pdf , [Accessed 6th Sept 2021]

[6] M. SATO, [The fourth industrial revolution and future education for ICT education in post Corona era] Daiyonjisangyoukakumei to kyouikuno mirai (in Japanese). Iwanami-booklet, 2021.

[7] K.Kouich, Y.Yuriko, M.Ujioka, H.Sasaki, D.Suzuki, [Work Revolution Destroys Schools and Teachers] Gakkou to kyousi wo kowasu hatarakikata kaikaku (in Japanese). Kadensya, 2020. 
[8] K.Toyama, Geek Hersey:Rescuing Social Change from the Cult of Technology, Misuzu Shobo, 2016.

[9] Japan Standard Education Research Institution, [Teachers are very busy though] Sensei ha Isogasii keredo-Tabou sono kadai to kaizen (in Japanese). Nihon Hyoujyun, 2017.

[10] J. A., Wicaksono, R. B. Setiarini, O. Ikeda, and A. Novawan, The Use of H5P in Teaching English, In The First International Conference on Social Science, Humanity, and Public Health (ICOSHIP 2020), pp. 227-230. Atlantis Press, 2021. DOI:https://doi.org/10.2991/assehr.k.210101.049

[11] J. RYAN, Reflections on Online English Instruction in Spring 2020 - Benefits and Drawbacks,2020. DOI:http://id.nii.ac.jp/1132/00001624/, [Accessed $6^{\text {th }}$ Sept 2021]

[12] M. Senoo, [Teachers don't give up too busy] Senseiga isogasisugiruwo akiramenai (in Japanese). Institution of Education Development Research (Kyouikukaihatu kennkyuujyo), 2017.

[13] S. Mitra, The hole in the wall: self-organising systems in education. New Delhi; New York, NY: Tata-McGraw-Hill Pub. Co. Ltd, 2006.

[14] Y. Hatakeyama, A Report on Online English Classes: Reflections and Implications, 2021. DOI:https://teapot.lib.ocha.ac.jp/records/2000042\#. YV2w27gzY2w, [Accessed $6^{\text {th }}$ Sept 2021] 